\title{
Resolution of antibody in autoimmune urticaria
}

\author{
Chrystyna Kalicinsky ${ }^{*}$, Shamim Wadiwall \\ From Canadian Society of Allergy and Clinical Immunology Annual Scientific Meeting 2011 \\ Quebec, Canada. 20-23 October 2011
}

Chronic urticaria, defined as widespread daily or nearly daily wheals for at least 6 weeks, with or without angioedema, impacts on patients' quality of life. Natural course is self-limited, with spontaneous remissions and occasional relapses. Antihistamines, leukotriene inhibitor, immunosuppressive agents are used. $60 \%$ are idiopathic and $40 \%$ are autoimmune due to presence of anti-IgE antibody or IgG autoantibodies against $\mathrm{Fc} \Sigma \mathrm{R} 1$. An association exists between chronic urticaria and autoimmune diseases. We report a case of a patient with autoimune urticaria, thyroid disease and vitiligo, who showed resolution of histamine releasing antibody (reflab) on remission.

In February 2005, a 44 yr old healthy woman was referred to the Allergy outpatient clinic with two month history of daily hives, moderately controlled with antihistamines, with good response to oral steroid. Lesions were pruritic, raised, erythematous, lasting for $<24 \mathrm{hrs}$ and resolved with purplish discoloration. Screening negative for malignancy, connective tissue disease. TSH normal. Histamine releasing antibody positive, maximum histamine release $27 \%(<16 \%)$. Skin biopsy confirmed chronic urticaria with neutrophils without vasculitis. Sulfasalazine was not tolerated, but control attained with antihistamines and leukotriene inhibitor. By one year, she failed trial of weaning medications.

6 months after presentation she developed vitiligo. 5 years later, she was hypothyroid. By 3 years, the urticaria was in complete remission without medications. Repeat histamine releasing antibody was negative.

There is a known association of severe chronic urticaria with auto antibody etiology and other autoimmune disease. Does resolution of antibody correlate with achieving remission? Further prospective studies are required to establish this relationship.

Published: 14 November 2011

University of Manitoba, Canada
doi:10.1186/1710-1492-7-S2-A35

Cite this article as: Kalicinsky and Wadiwall: Resolution of antibody in autoimmune urticaria. Allergy, Asthma \& Clinical Immunology 2011 7(Suppl 2):A35.
Submit your next manuscript to BioMed Central and take full advantage of:

- Convenient online submission

- Thorough peer review

- No space constraints or color figure charges

- Immediate publication on acceptance

- Inclusion in PubMed, CAS, Scopus and Google Scholar

- Research which is freely available for redistribution

Submit your manuscript at www.biomedcentral.com/submit

\section{Biomed Central}

\section{Biomed Central}

